April 1999 • NREL/CP-520-26230

\title{
Results from Undergraduate PV Projects at Seven Historically Black Colleges and Universities
}

R.D. McConnell

Center for Basic Sciences

National Renewable Energy Laboratory

Miami, Florida

March 16-18, 1999

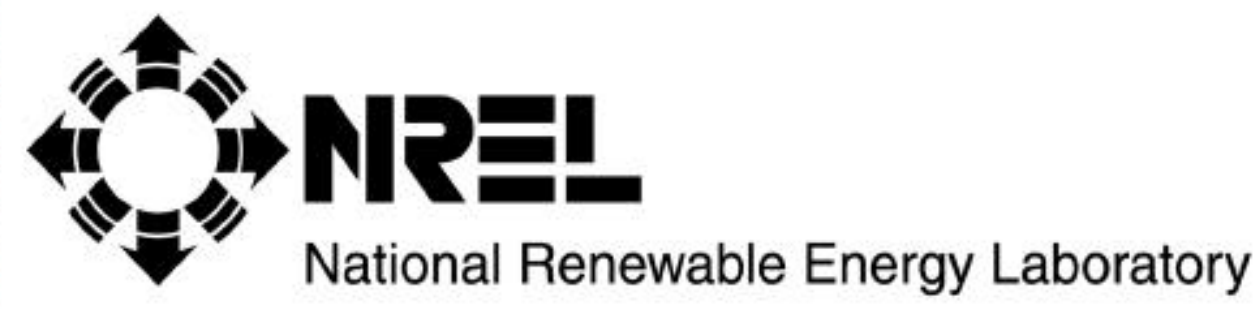

1617 Cole Boulevard

Golden, Colorado 80401-3393

NREL is a U.S. Department of Energy Laboratory

Operated by Midwest Research Institute $\cdot$ Battelle $\bullet$ Bechtel 


\section{NOTICE}

This report was prepared as an account of work sponsored by an agency of the United States government. Neither the United States government nor any agency thereof, nor any of their employees, makes any warranty, express or implied, or assumes any legal liability or responsibility for the accuracy, completeness, or usefulness of any information, apparatus, product, or process disclosed, or represents that its use would not infringe privately owned rights. Reference herein to any specific commercial product, process, or service by trade name, trademark, manufacturer, or otherwise does not necessarily constitute or imply its endorsement, recommendation, or favoring by the United States government or any agency thereof. The views and opinions of authors expressed herein do not necessarily state or reflect those of the United States government or any agency thereof.

Available to DOE and DOE contractors from:

Office of Scientific and Technical Information (OSTI)

P.O. Box 62

Oak Ridge, TN 37831

Prices available by calling 423-576-8401

Available to the public from:

National Technical Information Service (NTIS)

U.S. Department of Commerce

5285 Port Royal Road

Springfield, VA 22161

703-605-6000 or 800-553-6847

or

DOE Information Bridge

http://www.doe.gov/bridge/home.html 


\title{
Results from Undergraduate PV Projects at Seven Historically Black Colleges and Universities
}

\author{
Robert D. McConnell \\ Center for Basic Sciences \\ National Renewable Energy Laboratory (NREL), Golden, Colorado 80401
}

\begin{abstract}
In 1995, the NREL/Department of Energy (DOE) National Photovoltaics Program funded seven Historically Black Colleges and Universities (HBCUs) in its HBCU Photovoltaic Research Associates Program for a period of three years. The program's purpose is to advance HBCU undergraduate knowledge of photovoltaics, primarily as a result of research investigations performed, and to encourage students to pursue careers in photovoltaics. This paper presents results from PV projects ranging from fundamental materials research on PV materials to field projects of PV systems.
\end{abstract}

\section{INTRODUCTION}

The universities, funding, and periods of performance for the NREL/DOE HBCU Photovoltaic Research Associates Program are listed in the table below. In addition to these funds, about $\$ 100,000$ per year supported HBCU summer intern activities.

\begin{tabular}{|c|c|c|}
\hline Name/Location & $\begin{array}{l}\text { Total } \\
\text { Funding }\end{array}$ & Period of Performance \\
\hline $\begin{array}{l}\text { Central State University } \\
\text { Wilberforce, Ohio }\end{array}$ & $\$ 67,244$ & $10 / 6 / 95-10 / 5 / 98$ \\
\hline $\begin{array}{l}\text { Clark Atlanta University } \\
\text { Atlanta, Georgia }\end{array}$ & $\$ 236,748$ & $9 / 21 / 95-9 / 20 / 98$ \\
\hline $\begin{array}{l}\text { Clark Atlanta University } \\
\text { Vista University } \\
\text { Port Elizabeth. South Africa }\end{array}$ & $\$ 69,989$ & $10 / 31 / 95-10 / 30 / 98$ \\
\hline $\begin{array}{l}\text { Hampton University } \\
\text { Hampton, Virginia }\end{array}$ & $\$ 102,853$ & $10 / 9 / 95-10 / 8 / 97$ \\
\hline $\begin{array}{l}\text { Mississippi Valley State University } \\
\text { Itta Bena, Mississippi }\end{array}$ & $\$ 127,344$ & $10 / 6 / 95-10 / 5 / 98$ \\
\hline $\begin{array}{l}\text { Southern University and A\&M } \\
\text { College } \\
\text { Baton Rouge, Louisiana }\end{array}$ & $\$ 61,950$ & $9 / 28 / 95-9 / 27 / 98$ \\
\hline $\begin{array}{l}\text { Texas Southern University--School of } \\
\text { Technology } \\
\text { Houston, Texas }\end{array}$ & $\$ 67,848$ & $10 / 19 / 95-10 / 18 / 98$ \\
\hline $\begin{array}{l}\text { Wilberforce University } \\
\text { Wilberforce, Ohio }\end{array}$ & $\$ 190,630$ & $9 / 21 / 95-9 / 20 / 98$ \\
\hline
\end{tabular}




\section{CENTRAL STATE UNIVERSITY}

Central State University in Wilberforce, Ohio, has supported two PV Research Associates: Hakim Evans and Daniel Milo. Their most recent project involved working with representatives from Boone Water Systems (Dayton, Ohio) and Amarillo Pump and Supply Company (Amarillo, Texas) while they participated in constructing a wind/photovoltaic hybrid system on the Central State campus through August 1998. Central State has leveraged NREL's funding with that from NASA Lewis Research Center and the National Security Agency. The program supported by NASA Lewis (called CARET-“"Consortium for the Advancement of Renewable Energy Technology") parallels the DOE/NREL program and involves three additional universities. The National Security Agency project is oriented more toward lowdensity African languages and has renewable energy as a lower-priority part of the project. This project led to exchange visits with renewable energy workers from World Vision/Senegal and Hakim Evans.

Central State also created a five-day renewable energy community outreach program for 25 high school students. The course agenda included water resource management, wind energy, photovoltaics, and hybrid systems.

\section{CLARK ATLANTA UNIVERSITY}

Clark Atlanta University (CAU) in Atlanta, Georgia, had three PV Research Associates. Keenan Goodman is now a Masters degree candidate in the CAU Department of Physics, working on the topic "High-Performance Simulation of Air Pollution in Atlanta." Letetia Richardson has now completed all requirements for the Masters degree up to her thesis defense. She is currently a Ph.D. candidate in the Engineering Department at the University of Kentucky, Lexington. Jason Collins is a Masters degree candidate in the CAU Department of Physics, working on the topic "Characterization of InGaAs Heterostructures."

In a separate subcontracted effort, CAU and Vista University in Port Elizabeth, South Africa, jointly studied atmospheric effects on the performance of photovoltaic systems using a rotating shadowband pyranometer (RSP) located at Vista University. One impetus for the study is the potential impact on PV system performance of aerosols from coal fires used for cooking in South Africa. The RSP, manufactured by Ascension Technology, Inc., measures total-horizontal, direct-normal, and diffusehorizontal irradiance by analysis of data obtained by rotating a shadowband once per minute over a single light sensor. A matching system was installed at Clark Atlanta University for reference studies. 


\section{HAMPTON UNIVERSITY}

Thomas O'Neal and Bryan Thomas, architecture students from Hampton University, Hampton, Virginia, and summer interns at NREL during the summer of 1997, prepared drawings from plans of two buildings in the DOE/NREL Exemplary Buildings Program having integrated passive solar with energy-efficient building design. These drawings appear on NREL's Buildings and Thermal Systems Web site.

Natalie Bunkley, an architecture student from Hampton University and a summer intern at NREL during the summer of 1996, prepared several architecture sketches of an entrance gate for NREL's "Site Access Control Project." She also developed detailed cost estimates for several gate options. The outgrowth of her work will be NREL's new entrance gate to be completed before the end of 1998.

\section{MISSISSIPPI VALLEY STATE UNIVERSITY}

Mississippi Valley State University, in Itta Bena, Mississippi, lists the following objectives for its program: (1) familiarize the students with the issues surrounding photovoltaics; (2) educate the students on the primary and auxiliary technologies involved in solar power; (3) develop a solar power research base to accumulate knowledge and perform original research on different aspect of solar power utilization processes; and (4) expose the students to career and business opportunities in photovoltaics.

MVSU has been monitoring the solar energy profile from the rooftop of their Fielding Wright Science Building since 1985. The data are fed via modem link to NREL's central monitoring system. These measurements have also been instrumental in teaching the students to predict annual average power generation for various kinds of solar cells and to learn how the angle of solar incidence, type of cloud cover, and other factors affect the solar power signature. MVSU students have performed a series of tests to determine output characteristics of several photovoltaic panels as a function of solar incidence. MVSU held a symposium on photovoltaics on May 8, 1998, where three faculty members and seven students made presentations. The audience included the entire faculty and interested students from the Department of Natural Sciences and Environmental Health and concluded with a lively discussion among all.

MVSU is working with the following seven students on a variety of photovoltaic projects:

- Shawanda Shaw: Cost Analysis of Photovoltaic Equipment for Individual Houses

- Ramu Thiagrajan: Photovoltaic Industries Outlook for the Future

- Angela Rowe: Techniques for Setting Up PV Arrays and Measuring Power Output

- Tahida Pierre: Photovoltaic Energy Conversion Mechanisms

- Solomon Green: Solar Radiation: Power Versus Time Profile 
- Niki Wheeler: Manufacturing of Photovoltaic Modules

- Tijuanda Foster: Photovoltaics: The Energy of the Future.

In one of the MVSU reports, Ramu Thiagrajan noted: "I have had a chance to get firsthand experience with photovoltaic technology. Most importantly, I feel our research has contributed to building a safe and clean environment for the future."

\section{SOUTHERN UNIVERSITY}

Southern University in Baton Rouge, Louisiana, has the following mission statement: Southern University's project focuses on training and motivating African American students in future photovoltaic generation technologies, materials research, and education.

Southern University's PV program provided hands-on experience for a total of 10 students in preparing and characterizing semiconductor thin films (amorphous $\mathrm{Si}$, porous $\mathrm{Si}$, doped and undoped $\mathrm{CdTe}$ and $\mathrm{ZnTe}$ thin films) and solid electrolyte materials including glasses, single crystals, and thin-film samples for fuel cells, Li-ion batteries, and photovoltaic electrochemical solar cells using advanced spectroscopic and electrochemical techniques. Several of Southern's students have worked as summer interns at NREL.

One student, Tameka Page, worked at the PV Outdoor Test Facility at NREL during the summer of 1997. Later, upon graduation, she received employment offers from Rockwell International, Lockheed Martin, Schlumberger, and Lucent Technologies. She accepted a position with Schlumberger in January 1998.

Brandon Mayo worked as a summer intern at NREL during summer 1997 and summer 1998. His 1997 summer report was entitled "Strain in CdTe Thin Films." Because of his outstanding work, NREL invited Mayo to return for the summer 1998. He then worked with a research team studying recrystallization of close-spaced sublimation CdTe thin films. He is a co-author on a paper presented at the 1998 NCPV Review Meeting entitled "Induced Recrystallization of CdTe Thin Films Deposited by CloseSpaced Sublimation."

Denisechia Hawkins worked as a summer intern at NREL during the 1997 summer. Her summer report was entitled "The Effects of Cadmium Chloride Heat Treatment on Cadmium Telluride."

Kawambe Maye worked as a summer intern at NREL during summer 1998 on "Fabricating Fiber Optic Probes for Near-Field Optics." He developed a reproducible procedure leading to a very sharp taper for probes to be used in near-field optical microscopy for imaging semiconductor devices at nanometer scales. He also learned safety procedures appropriate for using the acids and solvents needed for his procedure. 
Isiak Akanbi, graduated in Electrical Engineering in summer 1996, followed by a Masters degree in physics in summer 1998. Akanbi says: "The NREL PV program at Southern University has encouraged me to pursue further studies. It provided me an opportunity for the leadership qualities necessary for developing and implementing the thesis research project necessary for a graduate degree. I am planning to choose a career in photovoltaic technologies."

\section{TEXAS SOUTHERN UNIVERSITY-SCHOOL OF TECHNOLOGY}

\section{Photovoltaic Research and Demonstration Laboratory}

In January 1997, Texas Southern University (TSU) of Houston, Texas, installed a 4 kilowatt PV system on the campus with funding from Houston Lighting and Power (HL\&P) and the Electric Power Research Institute. The successful installation and operation of the PV system has been an excellent educational tool for TSU and has provided a testbed and demonstration medium for local groups involved in promoting and testing PV technologies. Two arrays of $2 \mathrm{~kW}$ each were configured to provide DC (from one $2-\mathrm{kW}$ array) and $\mathrm{AC}$ (from the second array) to a variety of $\mathrm{AC}$ or $\mathrm{DC}$ appliances.

\section{TSU Renewable Energy and Environmental Protection (REEP) Academy}

Texas Southern University's School of Technology held its third annual REEP Summer Academy from July 12, 1998, through August 1, 1998. The REEP Mission Statement is the following: "TSU's School of Technology REEP Academy is a college preparatory program that encourages minority high school students to pursue education and careers in the math, science, engineering, and technology fields by presenting concepts in renewable energy and environmental protection through a combination of technical seminars, college preparatory courses, laboratory activities, field exercises, leadership development seminars, and community service projects." The REEP Academy is sponsored by the U.S. Department of Energy, National Renewable Energy Laboratory, Texas State Energy Conservation Office, Houston Industries/HL\&P, and the Port of Houston Authority.

Based on the successes of the previous years, the program was able to expand and include more technical sessions, laboratory and field experiments, and tours of local energy and environmental facilities. The program also included three major field trips: South Africa, West Texas A\&M's Alternate Energy Institute (Canyon, Texas), and the National Renewable Energy Laboratory.

The following topics were presented to the students during the two-week on-campus portion of the program: 
- Introduction to Renewable Energy: U.S. Department of Energy Perspective, $D r$. Allan Hoffman, U.S. Department of Energy, Acting Deputy Assistant Secretary, Office of Utility Technologies, Washington, DC

- The Infinite Power of Texas: Renewable Energy in Texas, Mr. Steven Wiese, Senior Associate, Planergy, Austin, TX

- Sustainable Buildings Design, Mr. George Bandy III, Sustainable Buildings Office, The University of Texas, Health Sciences, Houston, TX

- Passive Solar Energy/Building Solar Cookers, Mr. Mike Cormier, Program Director, The Energy Center, University of Texas, El Paso, TX

- Introduction to Photovoltaics, Mr. Abraham Ellis, Southwest Technology Development Institute, Las Cruces, NM

- Remote Sensing/Geographical Information Systems, Dr. Oscar Criner, Professor of Computer Science, Texas Southern University, Houston, TX

- Wind Energy Systems, Dr. Kenneth Starcher, The Alternate Energy Institute, West Texas A\&M, Canyon, TX

- Environmental Justice, Dr. Grover Hankins, Professor of Law, Texas Southern University, Houston, TX

- Natural Resource Conservation and Wildlife Protection, Mr. Carter Smith, Director, Katie Prairie Conservancy, Houston, TX

- Solar Water Heating, Mr. David Sawchak, President, Morningstar Enterprise, Houston, TX

- Pollution Prevention, Mr. Darryl Drenon, President, Drenon Environmental, Houston, TX

- Space Applications of PV, Mr. Mike Ewert, Senior Engineer, NASA Johnson Space Center, Houston, TX

\section{REEP South Africa}

TSU's School of Technology has established a collaboration with Port Elizabeth (PE) Technikon, in Port Elizabeth, South Africa, that has a solar energy training curriculum in their Electrical Engineering Department and is involved in the national utility's "Rural Schools Electrification Program" using photovoltaic systems. The South Africa REEP Mission Statement is as follows: "Through education and cultural awareness, REEP South Africa works with villages and rural communities to determine areas in need of improvement, and implement, when feasible, in conjunction with local technikons and universities, governments, and utilities, sustainable solutions to their infrastructural and developmental needs."

TSU has sponsored, with the help of DOE/NREL support, trips to South Africa for REEP honors students, PV Research Associates from the DOE/NREL subcontracted universities, and TSU instructors and staff. The trips took place during the summers of 1997 and 1998, and PV Research Associates from Wilberforce University, Central State University, and TSU participated. In July 1998, students and instructors from REEP South Africa and Port Elizabeth Technikon installed a PV panel and lighting in one of the homes of a village near East London, South Africa, with no electrical service. 


\section{WILBERFORCE UNIVERSITY}

Wilberforce University of Wilberforce, Ohio, had three students in their PV Research Associates program. Tosha Cameron worked on chemical etching of germanium. She worked in summer 1996 as an intern collecting energy-use data in Ghana with her advisor, Professor Tufah Habash, for an NREL PV proposal to the United Nations Development Program. In summer 1997, she worked with the Texas Southern University REEP program. Jeffrey Turner's project worked with PC1D computer modeling of solar cells. Raymond Haraway worked on the design, construction, and testing of a PC-based solar cell analyzer. Haraway also worked as a summer intern at the Institute of Energy Conversion at the University of Delaware in summer 1996, at the Florida Solar Energy Center in summer 1997, and in the Photovoltaics Branch at the NASA Lewis Research Center in summer 1998. Wilberforce, a neighbor to Central State University (also in Wilberforce, Ohio), is also a member of the NASAfunded Consortium for the Advancement of Renewable Energy Technology (CARET).

\section{THE NEXT THREE-YEAR PROGRAM}

In April 1998, NREL solicited proposals for the next three-year HBCU program. Final evaluation of the proposals was completed in November 1998 and new threeyear awards were negotiated with the following HBCUs: Central State University in Wilberforce, Ohio; Southern University A\&M College in Baton Rouge, Louisiana; North Carolina Central University in Durham, North Carolina; Mississippi Valley State University in Itta Bena, Mississippi; Texas Southern University in Houston, Texas; Howard University in Washington, DC; and Hampton University in Hampton, Virginia.

\section{CONCLUSION}

The HBCU PV Research Associates supported by the DOE/NREL program at a total funding level of over $\$ 400,000$ per year have worked on a variety of PV projects ranging from atomic level microscopy of PV materials to solar architecture to PV field projects. Considering the relatively small funding for this program and that the PV Research Associates are undergraduates in the beginning of their careers, the program has had some remarkable successes. Finally, as several of the students have indicated, the DOE/NREL HBCU PV Research Associates program has opened up new career possibilities for them in photovoltaics.

\section{ACKNOWLEDGEMENTS}

The principal investigators advising these HBCU undergraduates have performed admirably in meeting the goals and expectations for the DOE/NREL HBCU PV Research Associates Program. In particular, I appreciate the efforts of Professor Joshua Hill at Texas Southern University-School of Technology, Professor Clark Fuller at Central State University, Professor Rambabu Bobba at Southern University 
and A\&M College, Professor Gerald Grams at Clark Atlanta University, Professors Sallie Hood and Ronald Sakal at Hampton University, Dr. Herbert Smitherman and Edward Asikele at Wilberforce University, and Professor Baxish Balam at Mississippi Valley State University. 


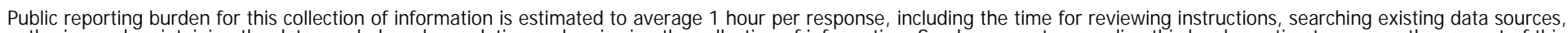

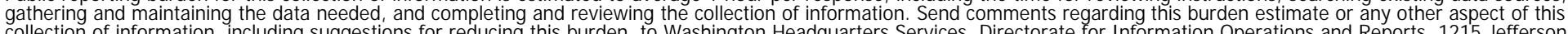

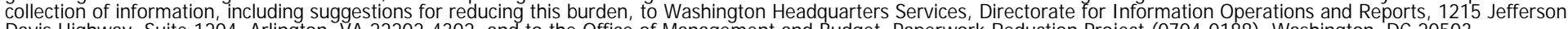



\begin{tabular}{|l|l|l|}
\hline 1. AGENCY USE ONLY (Leave blank) & $\begin{array}{l}\text { 2. REPORT DATE } \\
\text { April } 1999\end{array}$ & $\begin{array}{l}\text { 3. REPORT TYPE AND DATES COVERED } \\
\text { Conference Paper }\end{array}$ \\
\hline 4. TITLE AND SUBTITLE &
\end{tabular}

Results from Undergraduate PV Projects at Seven Historically Black Colleges and Universities 6. AUTHOR(S)

Robert D. McConnell

5. FUNDING NUMBERS

$\mathrm{C}$ :

TA: PV902601

7. PERFORMING ORGANIZATION NAME(S) AND ADDRESS(ES)

National Renewable Energy Laboratory

8. PERFORMING ORGANIZATION

1617 Cole Blvd. REPORT NUMBER

Golden, CO 80401-3393

9. SPONSORING/MONITORING AGENCY NAME(S) AND ADDRESS(ES)

10. SPONSORING/MONITORING AGENCY REPORT NUMBER

CP-520-26230

11. SUPPLEMENTARY NOTES

12a. DISTRIBUTION/AVAILABILITY STATEMENT

National Technical Information Service

12b. DISTRIBUTION CODE

U.S. Department of Commerce

5285 Port Royal Road

Springfield, VA 22161

13. ABSTRACT (Maximum 200 words)

In 1995, the NREL/Department of Energy (DOE) National Photovoltaics Program funded seven Historically Black Colleges and Universities (HBCUs) in its HBCU Photovoltaic Research Associates Program for a period of three years. The program's purpose is to advance HBCU undergraduate knowledge of photovoltaics, primarily as a result of research investigations performed, and to encourage students to pursue careers in photovoltaics. This paper presents results from PV projects ranging from fundamental materials research on PV materials to field projects of PV systems.

14. SUBJECT TERMS

photovoltaics ; Historically Black Colleges and Universities ; HBCU

\begin{tabular}{l|l|l}
\hline 17. SECURITY CLASSIFICATION & 18. SECURITY CLASSIFICATION \\
OF REPORT & OF THIS PAGE \\
Unclassified & Unclassified & $\begin{array}{l}\text { 19. SECURITY CLASSIFICATION } \\
\text { OF ABSTRACT } \\
\text { Unclassified }\end{array}$ \\
\hline
\end{tabular}

NSN 7540-01-280-5500
15. NUMBER OF PAGES

8

16. PRICE CODE

Standard Form 298 (Rev. 2-89) Prescribed by ANSI Std. Z39-18 